\title{
FABULYA ZOLTÁN:" \\ Hőkezelési folyamat modellezési adatainak előkészítése, elemzése húskonzerv-gyártás gázfogyasztásának optimálásához
}

\begin{abstract}
Summary
We have been looking for the possibility to build a computer model of costly gas utilization in the course of heat treatment of canned meat. This was necessary for us, as the first part of our long-term research, to be able to accomplish minimized costs by synchronizing heat treatment processes running side by side and by production programming to define completion time of the cans. First, because of our multiple data (paper based, text file, image file, Excel file), we have arranged them under a common user interface, while defining the best one from the data with different precision appearing in several sources. Based on the accurate data we did correlation and regression analysis to define the data influencing the gas consumption and to see whether our present data was enough to develop a model. Since the furnace has to ensure the steam supply of the heat treatment equipment and the heating of the buildings too, we defined the gas consumption of the furnace which is dependent on the environmental temperature.
\end{abstract}

\section{Bevezetés}

Húskonzervet előállító vállalatok számára jelentős költséggel jár a hökezelés folyamata. E költségek közül csak a fütőgázra fordítandót vizsgáljuk, mely két részből tevődik össze. Az egyik, jelentősebb rész a felhasznált mennyiség költsége, a másik a felhasználásra lekötött gázmennyiségé. Ez utóbbi nagyfogyasztók esetén kötelező, meg kell adniuk fél évvel korábban a következỏ egy évre vonatkoztatva az oránként felhasználandó gázmennyiségük felsỏ határát. Ha viszont ezt egy hónap folyamán akár csak egy óra alkalmával túllépik, akkor a túllépés mértékével arányos további igen magas, büntető jellegü költséget kell fizetniük (www.egaz-degaz.hu/hu). Tehát változatlan gázfelhasználás mellett a költség lehet kissé alacsonyabb, amennyiben kisebb lekötött mennyiséget kérnek, de ezzel kockáztatva az esetleges túllépés miatti sokkal magasabb fizetendő összeget. E probléma miatt indokolt a vállalat gázfogyasztásának modellezése, az optimális lekötött gázmennyiség meghatározása.

A modell meghatározásához adatgyüjtés és adatelökészítés után az adatok elemzésével eldönthetjuik, hogy adataink alkalmasak-e a gázfogyasztás modellezésére, s melyek a gőzfogyasztást befolyásolók. E munkánkban bemutatjuk ez irányú kutatómunkánkat, eredményeinket.

A modell ismeretében gyártásprogramozással a hókezelendó termékek beérkezési ideje, további várakoztatással a hőkezelési folyamat megkezdése ütemezhetővé válik. Így elkeruilhető a párhozamosan zajló folyamatok intenzív gőzigényü fázisainak találkozásából származó csúcsok kialakulása, és az ebből származó esetleges lekötött gázmennyiség feletti felhasználás, vagyis meghatározható és alacsonyabb szinten tartható a lekötött gázmenynyiség értéke. Távlati célunk e gyártásprogramozás és ütemezés megvalósítása, melynek alapját az elkészuilt modell biztosítaná.

\section{Anyag és módszer}

A hökezelést zárt, nyomástartó berendezésekben (autoklávokban) végzik, melyekböl jellemzően 10-20 tudja biztosítani (Eszes et al., 2003) a több gyártósorról eltérő ütemben érkező, különböző méretü, geometriájú, tartalmú konzervek hőkezelését. Egy berendezés-

" Adjunktus - Szegedi Tudományegyetem Mérnöki Kar. 
ben akkor indul el a hőkezelési folyamat, amikor az azonos hőkezelési előírású termékekböl összegyült mennyiség tele töltetet eredményez. Így biztosítható a minimális fajlagos költség. Az elöirások termékenként tartalmazzák az elérendő hőmérsékletet, a felfütési idöt, a hőntartási időt és a hütési időt. Automatika szabályozza az előirások betartását a megfelelö gőzmennyiség adagolásával a felfütési és hỏntartási fázisban, míg a hütés során hütővíz bevezetésével. Az 1 . ábra felső részén az idő függvényében látható az elöírt hömérséklet (ismert adatok), alatta az ehhez szükséges gőz tömegáram idöbeli alakulása (ismeretlen, meghatározand6).

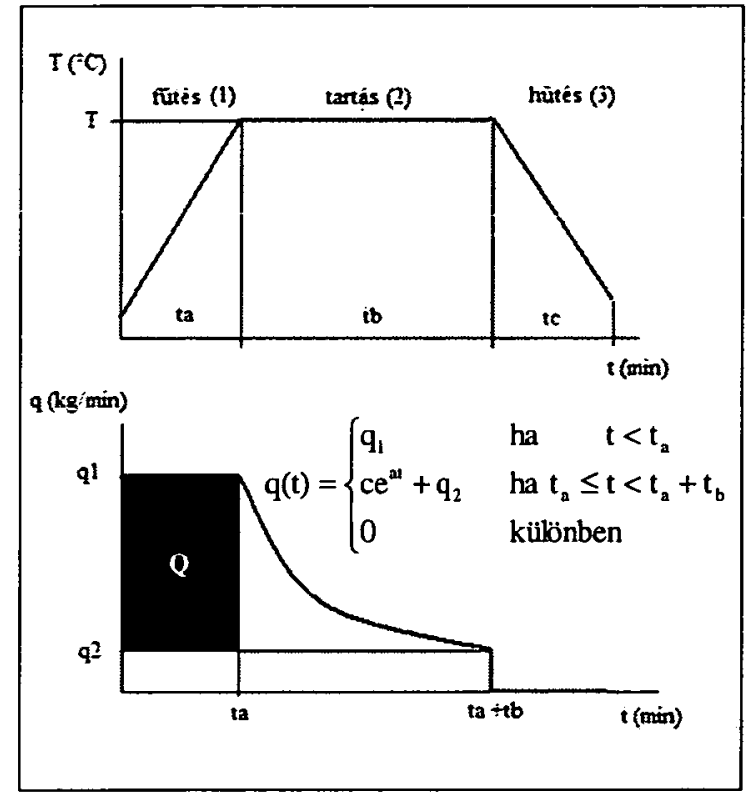

1. ábra. Az elōírt hõmérséklet és a gōz tömegáram idõbeli alakulása (Forrás: A szerző saját szerkesztése)

Ismert, termékfüggő adatok:

$\mathrm{T}$ - elérendö hömérséklet $\left({ }^{\circ} \mathrm{C}\right)$

$\mathrm{t}_{\mathrm{a}}-$ felfütési idö (perc)

$t_{b}-$ hỏntartási idő (perc)

$\mathrm{t}_{\mathrm{c}}$ - hütési idő (perc)

Meghatározandó:

$\mathrm{q}(\mathrm{t})$ - göz tömegáram $(\mathrm{kg} /$ perc $)$

$\mathrm{Q}$ - felfütés gőzigénye $(\mathrm{kg})$

$\mathrm{q}_{2}$ - gőz tömegáram vesztesége ( $\left.\mathrm{kg} / \mathrm{perc}\right)$

$\mathrm{c}, \mathrm{a}-\mathrm{q}(\mathrm{t})$ függvény paraméterei

A modell ismeretében megkaphatjuk az egyes berendezések gõzigényének időbeli alakulását, mely függ a kezelendő termékektöl (így a hökezelési elöírástól) és a kezdési idöpontoktól. A 2. ábrán három párhuzamosan müködő berendezés modellezéssel kapott gözfelhasználása látható egy nap folyamán (három müszak). 


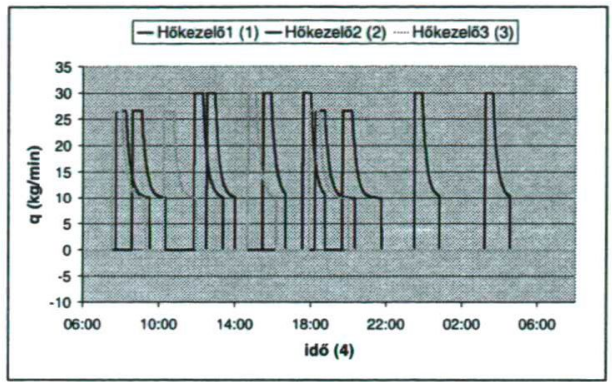

\section{2. ábra. Gõzfogyasztás három párhuzamosan mũködõ berendezésben} (Forrás: A szerző saját szerkesztése)

Az egyes berendezésekre kapott értékek összegeként kapjuk a hőkezelések együttes gőzigényét az idő függvényében (3. ábra), melyet egy gázfütésủ kazánnak kell biztosítania.

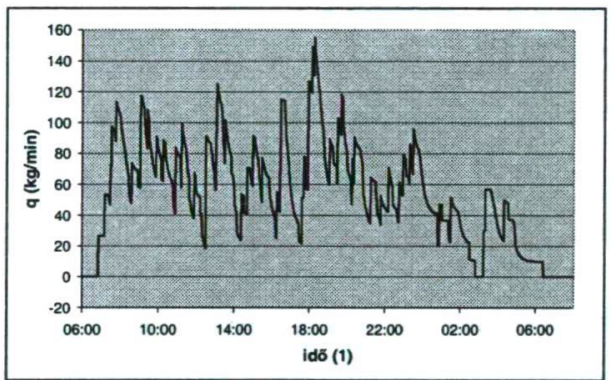

3. ábra. Több párhuzamosan mũködõ berendezés összegzett gőzfogyasztása

(Forrás: A szerző saját szerkesztése)

A 2. és 3. ábra modellünk kezdeti paraméterértékei mellett adódtak az adatokat biztosító vállalatnál egy nap alkalmával ténylegesen lejátszódó hőkezelések alapján. A paraméterértékek finomítása legegyszerübben úgy történhetne, ha mérések alapján ismert lenne a hőkezelő berendezések egyenkénti, vagy rosszabb esetben együttes gőzfelhasználása az idő függvényében. De ilyen adatok nem voltak, $s$ a vállalat nem is tervezi csak a modell egyszerübb meghatározásához szükséges igen költséges müszer beszerzését. Ezért a modell paramétereinek pontosítása a gőzt előállító kazánnál mért gázfelhasználás alapján történhet. Viszont itt újabb problémába ütköztünk. A gáztüzelésű kazánnak a hőkezelő berendezések gőzellátásán túl feladata az épületek, irodák fütése is téli időszakban. Emiatt kérdéses a modellezés adatellátottságának elegendősége, valamint szükséges a rendelkezésre álló adatok, anyag- és erőforrás-áramlások (4. ábra) részletesebb vizsgálata.

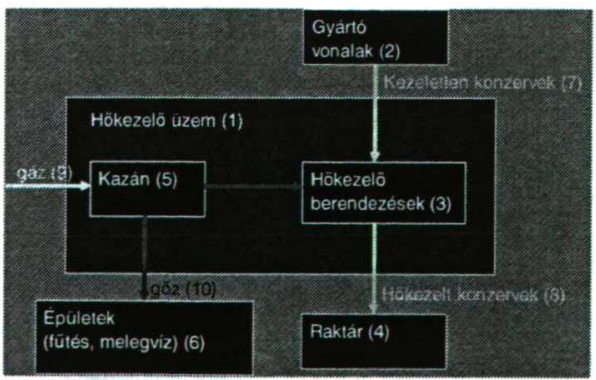

4. ábra. Anyagok és erőforrások áramlása (Forrás: A szerző saját szerkesztése) 
A gázfogyasztás modellezéséhez szükséges kinyerhető adatok:

- A hőkezelendő termékek esetén a sajnos nem mérhető gőzfogyasztás helyett:

○ A hőkezelés megkezdésének időpontja,

○ Tömeg,

○ Hőkezelési folyamat lefolyása:

- Elért hömérséklet,

- Felfütési idő,

- Hőntartási idő.

- Fütési időszakban a fütésre fordított gőzfogyasztás helyett:

o hömérséklet.

- A felhasznált gázra vonatkozó rendelkezésre álló adatok:

○ A fogyasztott mennyiség időbeli alakulása, mely alapján tesztelhető modellünk jósága.

Hipotézisünk szerint összefüggésnek kell mutatkoznia a hőkezelt termékmennyiség és a felhasznált gáz mennyisége között. Amennyiben az így kapott korreláció nem mutat elegendően szoros kapcsolatot, akkor az épületek fütésére fordított gőzmennyiség adatának hiányában a korrelációs vizsgálatokba be kell vonnunk az ismert környezeti hőmérséklet adatokat is, mely ezt helyettesítheti. Ha ekkor sem kapnánk megfelelő korrelációt, más alapokra kellene helyeznünk a modell kialakítását. Ellenkező esetben lineáris regressziós vizsgálattal kaphatjuk meg a gyártóvonalakról érkező ismert termékmennyiség (és esetleg a hőmérséklet) függvényében a felhasználandó gázmennyiséget.

Az elérhető adatok a következő változatos formában állnak rendelkezésre:

1. Hőkezelési napló fájl (xls fájl, kézzel begépelt adatokkal):

- Berendezés sorszáma (melyben történt a kezelés),

- Termék neve,

- Tömeg,

- Hőkezelés kezdési és befejezési időpontja.

2. Egy berendezésben egy hőkezelési folyamat befejezésekor automatikusan generálódó fájlok (jpg képfájl)

- Az idő függvényében látható a hőkezelés hőmérsékletének alakulása (5. ábra);

- A fájl nevében lévő adatok:

- Befejezés időpontja,

- Berendezés sorszáma,

- Hökezelési elöírás kódszáma.

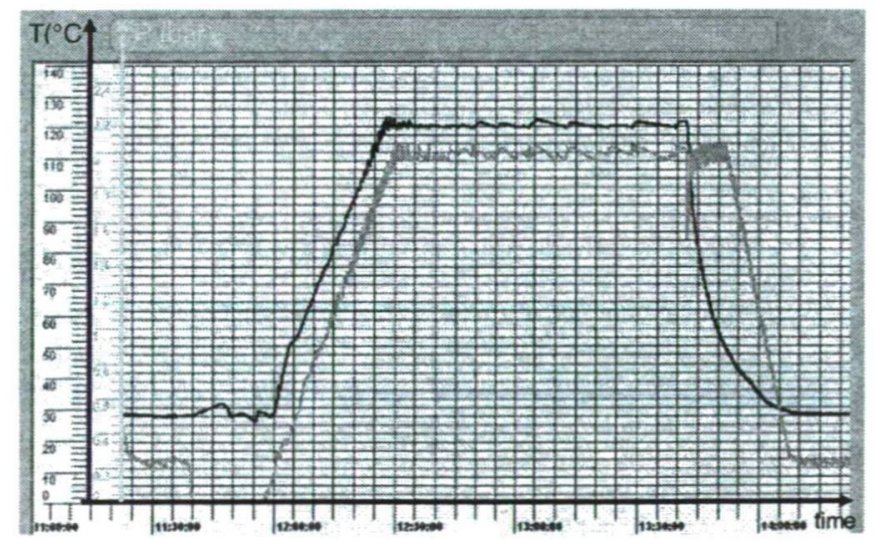

5. ábra. Egy berendezés egy hōkezelési folyamatát megjelenítõ képfájl

(Forrás: A szerző saját szerkesztése) 
3. Termékekre vonatkozó hőkezelési elöírások (Papír):

- Hökezelési elöírás kódszáma,

- Elérendő hőmérséklet,

- Felfütési idő,

- Hőntartási idő,

- Hütési idő.

4. Óránkénti gázfogyasztás (txt szövegfájl):

- Egy órás időintervallumban fogyasztott mennyiség (m3),

- Az intervallum kezdő időpontja,

- A gáz hömérséklete (mely fütési időszakban a légköri, ,időjárási” hőmérsékletnek tekinthető).

\section{Eredmény és értékelés}

Adatainkat először egy közös felhasználói felületen kezelhetővé hoztuk. Erre a célra az Excel környezetet találtuk a legalkalmasabbnak. Itt elvégezhető a modellezés, valamint a korreláció és regresszió analízis is. A papír alapú adatokat begépeltük, a szöveg (Txt) fájlokat importáltuk, míg a kép (jpg) fájlok nevéből megfelelö DOS (dir) parancs kimenetének átirányításával text fájlt készítettünk, melyet már tudtunk importálni.

Egyedül a képfájlok tartalmában látható adatok kinyerése nem volt automatizálható. Ezekre azért lett volna szükség, mert a ténylegesen bekövetkezett, pontos, automatizált mérésen alapuló értékeket tartalmazta, szemben a naplófájl kézi begépelésủ adataival. A hőkezelés pontos kezdeti időpontjának meghatározása okozta a legnagyobb problémát. A jpg fájl neve a pontos befejezési időpontot tartalmazza, valamint a hökezelési elöírás kódszámát, mely alapján megkapható a hökezelés elöírás szerinti időtartama. Ebböl számítható a kezdés időpontja, amit néha még korrigálni kell a képfájl alapján csak szemmel látható előírásokhoz képesti felfütési idő megnövekedése miatt, melyet az elégtelen gőzellátás okoz. Egy ilyen esetet mutat a 6 . ábra, melyen az elöírásoknak megfelelö lineáris felfütési fázist nem sikerült betartani. A pontos adat tehát három forrásra támaszkodott: a képfájl nevére, tartalmára és a hökezelési elöírások adataira.

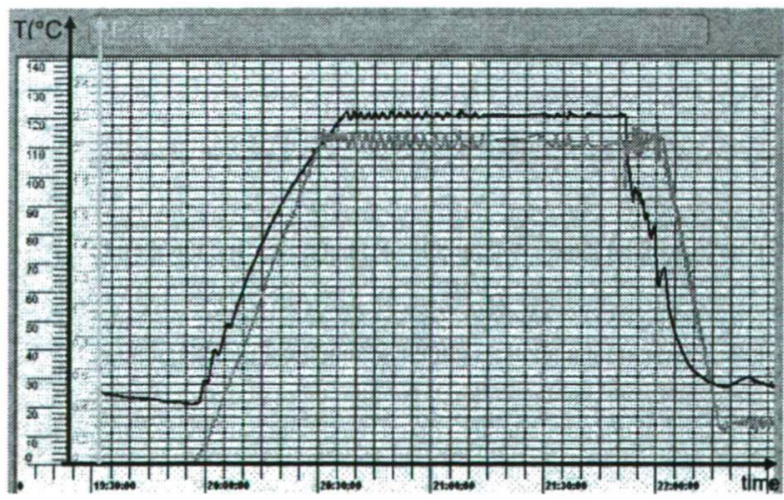

6. ábra. Elégtelen gõzellátás (Forrás: A szerző saját szerkesztése)

A pontos adatok birtokában elöször arra kerestük a választ, hogy a napi hőkezelt termékmennyiség és a napi gázfogyasztás között kellően szoros-e a kapcsolat. Ekkor még nem vettük figyelembe, hogy az épületek fütésére is fordítódik fütési időszakban valamekkora rész a kazán által termelt gőzből. A vizsgálathoz szükséges napi gázfogyasztást az óránkénti adatok 6:00-6:00-ig adódó összegeként, míg a hőkezelt termékmennyiséget a 
naplófájl adatainak naponkénti összesítésével kaptuk a 09.12-11.16 időszak munkanapjainak esetében. A korreláció 64\%-ra adódott, mely alacsony érték nem mutatott kellően szoros kapcsolatot, modellezésünk valamilyen hibájára utalt. Emiatt részletesebben megvizsgáltuk eredményeinket, elemeztük a lineáris regresszió egyenesétől való eltéréseket ( 7 . ábra), melyek pár kivételtől eltekintve október 15 előtti is utáni napok esetében ellentétes előjelüek voltak. Október 15 volt a fütési időszak kezdete, tehát a gázfogyasztás modellezésében szerepet kellett kapnia a fütésnek, mely a hömérséklettel mutathat összefüggést.

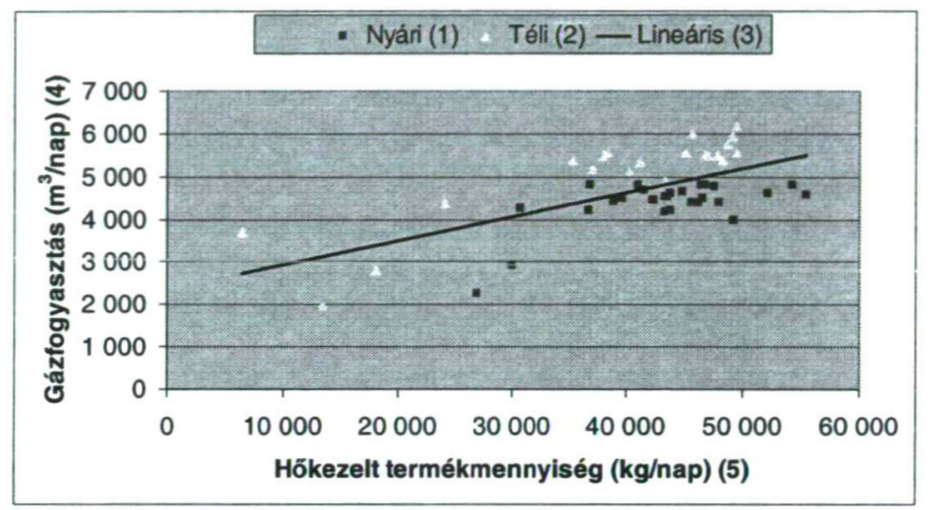

7. ábra. Nyári és téli napokon mért gázfogyasztás a termékmennyiség függvényében

(Forrás: A szerző saját szerkesztése)

Következő lineáris regresszió és korreláció vizsgálatunk már csak a fütési időszakban kereste a kapcsolatot a termékmennyiség és a hőmérséklet függvényében a gázfogyasztással. Ekkor már kellően szoros kapcsolatot kaptunk, s így értelmezhettük a lineáris regreszszióra kapott adatokat is:

- Korreláció: $91 \%$.

- A koefficiensek a tengelymetszet kivételével 5\% alatti hibát jeleznek.

$-1{ }^{\circ} \mathrm{C}$ hőmérséklet csökkenés $98 \mathrm{~m}^{3}$ gázfogyasztás növekedéssel jár.

$-1 \mathrm{t}$ termékmennyiség változás $75 \mathrm{~m}^{3}$ gázfogyasztás változást okoz.

\section{Következtetések}

A keresendő modellhez szükséges információk nehezen hozzáférhetők, adattisztítás után rendelkezésünkre állhatnak.

A fütés gázigénye valószínüleg elkülöníthető a hőkezelés igényétől.

Távlati cél a jelenleg kézi vezérlésủ - a gyártósorral kezdődő - ütemezési problémának a korlátok betartását biztosító számítógépesítése.

\section{Irodalomjegyzék}

Eszes, F., Rajkó, R., Szabó, G. (2003): Energia- és vízfelhasználás-csökkentés lehetőségeinek feltárása a húsiparban. 10 Symposium on Analytical and Environmental Problems, MTA Szegedi Akadémiai Bizottság Kémiai Szakbizottság Környezetvédelmi és Analitikai Munkabizottsága,

Szegedi Tudományegyetem, Szeged, 2003. szeptember 29. Proceedings, pp. 169-174.

www.egaz-degaz.hu/hu (letöltve 2008.05.19.) 